\title{
Om tankebilledet i Grundtvigs sidste digt. II
}

\section{Af William Michelsen.}

Fra først til sidst var Grundtvig en visionær digter og tænker. Han ikke blot digtede, men tænkte også i visioner, i syner. Han så tankerne for sig. Derfor er det forkert at opfatte hans digtning og tænkning under anvendelse af antikke billeder som færgemanden Karon, mens han sagtens kan bruge et almindeligt udtryk som »fra vugge til grav« eller at have et ord at skulle have sagt »på falderebet«, dvs. lige inden man tager afsked uden at det derfor er for evigt. Men billedet af menneskets eksistentielle situation over for døden er i 2 . strofe af Grundtvigs sidste digt ikke til at tage fejl af. Det er, trods Grundtvigs kristne tro - ganske som i salmen At sige Verden ret Farvel - præget af den natlige rovfugls tuden, hvadenten det er kysten af de dødes rige eller undergangen i det bundløse hav, han forestiller sig.

I denne situation står forstanden stille, og forestillingen om paradiset er så fjern, som den nogensinde kan være, når man tænker på jordisk vis. Og det er ganske rigtigt, at tanken om Jakobs drøm om stigen op til Guds rige i Det Gamle Testamente også er præget af forfærdelse. Men den betyder ikke desto mindre, at Gudsriget er os nær, selv i dødsriget, nemlig overalt hvor mennesket priser Gud - som i Davids 139. Salme, som det havde været rigtigere at henvise til i min første artikel om tankebilledet i Sidste Digt (Grundtvig Studier 1995, 102ff).

Men dermed er Grundtvig også kommet over det kritiske punkt i tanken om døden. Forestillingen om Sjælefærgen, som han er ved at entre op i, har sit faste holdepunkt i billedet af forstavnen på skibet: »Sjæle-Færge-Stavnen«. Den er vendt mod det usynlige mål for sejladsen, der med ét viser sig for ham, som når tågen letter foran indsejlingen til havnen, fordi Guds ord hele tiden har været det sikre mål, der styredes imod ved hjælp af Gudsordets kompas.

Man forestiller sig ofte Grundtvigs kristendom som en alt for nem vej til himmelhavnen. Men Bent Noacks fortolkning af digtet, som han oprindeligt forelagde os ved Grundtvig-Selskabets årsmøde i Århus, fængslede mig netop, fordi den bestemt modsiger, at Grundtvigs tanke om døden var alt for nem. Pointen i Noacks foredrag, der er trykt i Vartovbogen 1993 ( s.102-112), er - som fremhævet af Fl. LundgreenNielsen (Grundtvig Studier 1994, s.116) - hans st $\varnothing$ tte til den »maritime« fortolkning af det gode danske udtryk: »Nu jeg staaer paa Falderebet/ Ved det store,vilde Hav .. « 
Uden at slippe det, der binder os til denne Jord, får vi ikke indbydelsen til Guds-Bordet. 